\title{
The Local Fabrication of School Statistics
}

Actors, Practices and Issues at Stake in a Primary School in Benin

\section{Sarah Fichtner}

\section{(2) OpenEdition}

\section{Journals}

Electronic version

URL: http://journals.openedition.org/anthropodev/666

DOI: $10.4000 /$ anthropodev.666

ISSN: 2553-1719

Publisher

APAD - Association pour l'anthropologie du changement social et du développement

\section{Printed version}

Date of publication: 1 December 2018

Number of pages: 43-65

ISBN: 979-10-93476-06-3

ISSN: 2276-2019

\section{Electronic reference}

Sarah Fichtner, "The Local Fabrication of School Statistics », Anthropologie \& développement [Online], 48-49 | 2018, Online since 18 July 2019, connection on 19 August 2019. URL : http:// journals.openedition.org/anthropodev/666 ; DOI : 10.4000/anthropodev.666

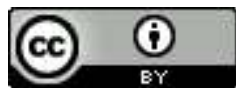

La revue Anthropologie \& développement est mise à disposition selon les termes de la Licence Creative Commons Attribution 4.0 International. 


\title{
The Local Fabrication of School Statistics
}

\section{Actors, Practices and Issues at Stake in a Primary School in Benin}

\author{
Sarah Fichtner
}

\begin{abstract}
Fondé sur une recherche ethnographique de 12 mois dans une école primaire en zone rurale au Bénin en 2012/13 et 2014, I'article s'intéresse aux "petits arrangements » autour de la fabrique locale des statistiques scolaires: entre exigences internationales, stratégies et marges de manœuvre locales. Au travers des exemples de deux variables clés qui informent la politique internationale de l'Éducation pour tous - l'effectif des élèves et leurs taux de redoublement -, l'étude montre comment les acteurs impliqués dans l'arène scolaire font, représentent et gouvernent leur école par les chiffres. Dans cette perspective, les représentations chiffrées constituent surtout des outils de la micropolitique scolaire (notamment par rapport aux ressources budgétaires et à la réputation de l'école) et de l'(auto)contrôle bureaucratique de ses acteurs, plutôt que des instruments fiables pour informer et contrôler la macropolitique du développement.
\end{abstract}

Based on 12 months of ethnographic research in a primary school in rural Benin in 2012/13 and 2014, this paper focuses on the "little arrangements" organised around the local fabrication of school statistics which arise from the interaction between demands at international level, and strategies given room for manoeuvre at local level. Based on two key variables central to international policies of Education For All, namely school enrolment and repetition rates, this study shows how the actors involved in the school arena represent, govern and "do the school" through the production of these numbers. The data demonstrates that school statistics reflect the results of micro-political strategies to enhance budget allocation and school reputation, and reflect the bureaucratic (self) control of the actors involved, rather than being reliable instruments that can inform or measure macro policies of development. 


\section{Introduction $^{1}$}

With the rise of "neo-liberal bureaucratization" technologies (Hibou, 2013), focusing on effective management, benchmarking and accountability in the public sector (Bruno and Didier, 2013; Ozga et al., 2009), and within the framework of the global partnerships set up to achieve the Millennium Development Goals - including Education For All -, the quantity, quality and necessity of statistical production have changed, particularly in the countries of the Global South. The field of statistics is no longer an exclusive domain of the central State $^{2}$. It is, in addition, a mechanism for informing and (self) monitoring a public action that involves different actors in "partnership" 3 . Established for a "more effective" government of public policies, this device affects every aspect of the daily life of institutions, such as schools in the education sector or hospitals in the field of health, where data is produced which then feeds into national and international indicators.

The analytical perspective that guides this article is based on studies on statistics and indicators as representations, practices and "quantification technologies" which contribute to the production of globalized governmental knowledge (Rottenburg et al., 2015; Samuel, 2013). In addition, it is influenced by scholarship that analyzes "governance by

\footnotetext{
${ }^{1}$ This is the English version of an article that was written in French ("La fabrique locale des statistiques scolaires : acteurs, pratiques et enjeux dans une école primaire au Bénin") for the Revue d'Anthropologie des Connaissances, vol. 10, number 2, 2016, pp. 261-278 (DOI: 10.3917/rac.031.0261). It has been part of the special issue "Measurements and standards: Political technologies in African government" directed by Lydie Cabane \& Josiane Tanchou. It has been presented at the APAD conference 2015 in Cotonou. The author thanks those present at the conference, the anonymous peer reviewers, the editorial board at the Revue d'Anthropologie des Connaissances and the coordinators of the special issue for their stimulating comments. It is published in Anthropologie \& Développement with the consent of the editors of the Revue d'Anthropologie des Connaissances. For further information contact Marc Barbier, Société d'Anthropologie des Connaissances, UMR LISIS, université Paris-Est Marne-la-Vallée.

2 The term "statistics" derives in its etymology from the notion of knowledge about the State (Desrosières, 2000: 16; Foucault, 1991: 138).

${ }^{3}$ The term "partnership" is placed in quotation marks to indicate its problematic neoliberal ideological conceptuality that tends to mask the unequal power positions between "developers" and "developing countries" (see Abrahamsen, 2004; Lange, 2003).
} 
numbers" (Ozga et al., 2009) as a "political technology of the self" (Shore and Wright, 2000: 62) with reference to Foucault (1994) and Rose (1991). This device, studied here through the process of the local fabrication of statistics ${ }^{4}$, "responsibilizes" the actors in their self-assessments in accordance with the conditionalities imposed to positively influence their reputation and, further on, their career (Merry, 2011: S90) ${ }^{5}$.

Despite the growing interest in analyzing the transformation, effects and sociopolitical limits of "school measurements" (Normand, 2005, 2006; Cusso, 2008; Deleigne, 2004; Garcia, 2002; Gérard and Pilon, 2005; Samuel, 2013; Vinokur, 2008), very few studies address what is the focus of this article: the production of school statistics at the "grassroots level".

Based on ethnographic research of everyday life in a public primary school in a village in north-eastern Benin called Alafia, I am interested in the "adapted" fabrication of two key variables that inform the international policy of Education For All: the number of pupils, which enters for example into the calculation of the school enrolment rate of a locality ${ }^{6}$, and the overall repetition rate of the school, which is an ingredient for measuring the internal efficiency of the education system.

In doing so, I study the local arena of the school in the context of the "new global school order" (Lange, 2003; Laval and Weber, 2002) promoting universal basic education not only as an objective in itself, as a human right, but also as one of the main instruments - and indicators - of poverty reduction and economic and human development (Bianchini, 2008; Cusso, 2008). In this context, governance through structural

\footnotetext{
${ }^{4}$ See also Fichtner (2014a).

${ }^{5}$ According to Merry (2011: S90) the "turn to indicators is part of a new form of governance, one that engages the person in governing himself or herself in terms of standards set by others. This new form of governance emphasizes "responsibilization", in which individuals are induced to take responsibility for their actions [...]. In some of the most successful examples, such as grades in school, the indicator comes to shape subjectivity, defining for the individual his or her degree of merit".

${ }^{6}$ According to the commonly accepted statistical definition, the (primary) enrolment rate refers to the ratio of the number of children enrolled in primary school who belong to the age group that officially corresponds to primary schooling (numerator), divided by the total population of the same age group (denominator). This ratio is in fact called "net enrolment rate" (Gérard and Pilon, 2005: 202).
} 
adjustment and conditional austerity of the 1980s and 1990s has been replaced - at least in development discourse - by governance based on "voluntary funding initiatives" implying models of "partnership" such as the Fast Track For Education For All (Samuel, 2013: 263) 7 . These initiatives are accompanied by instruments that measure their impact through comparable indicators in order to support the definition of precise policy orientations and their implementation from a distance.

It is not our primary concern to discuss the "poor quality" of statistics (Jerven, 2013), as not necessarily representing a reliable instrument for informing and monitoring (macro) educational policy or for changing local practices (although my case studies also show that this is the case). Rather, my intention is to focus on the (micro)political processes (Ball, 1987) by which local actors, namely the school principal and the parents committee, make, manipulate and "adapt" school statistics. Through this process, these actors follow their own interests by exploiting the "room for manoeuvre" built into the "remote" control of the school arena. Far from presenting a harmonious space, this arena proved to be "a place of concrete confrontations of social actors interacting on common issues" (Bierschenk and Olivier de Sardan, 1998: 262), a "zone of negotiation" (Rottenburg, 2002: 234) around "representation practices" (ibid.: 14).

Addressing the day-to-day functioning of the school through its "practical norms" (Olivier de Sardan, 2014: 407) and grasping the "real" comportment of its actors by analyzing its encrypted and listed bureaucratic procedures, makes it possible to differentiate analytically between the actual management of the school from its image presented on paper. The production of statistics is not only a tool for informing the State, NGOs and technical and financial partners on the school's functioning or progress; it is also a tool of local governance in a globalized context. It shapes the relationship between the school principal and parents, the funding mechanisms of the school, and the provision of

\footnotetext{
${ }^{7}$ The Education For All (EFA) Fast Track Initiative was launched in 2002 and is administered by the World Bank. It brought together all major donors and developing countries whose strategy for achieving the EFA goals, developed in their National Education Plans, was considered "good" and "credible". In 2011 the initiative was renamed the Global Partnership for Education, see www.globalpartnership.org (accessed 20/03/2015).
} 
textbooks and food for the school canteen. Through the creation of classes and manipulation of repetition rates, the production of statistics impacts on wider school selection processes. In this sense, the fabrication of statistics constitutes a "political technology of the self" through which actors manage and justify their actions which impact on their material situation as well as on their reputation and career. For instance, they open new classes and inflate numbers to increase the enrolment rate in "their" school and they select repeaters to improve "their" success rate in exams. I cover these two examples of the fabrication of statistics in the two sections below.

My ethnographic research of 12 months in 2012/13 and 2014 consisted of participant observation of the school's daily life, the consultation of school documents, and semi-structured interviews and conversations with actors in the school arena (the school principal, teachers, parents, pupils, NGOs, local authorities, administrators, but also representatives from the Ministry of Education and the office in charge of education at the level of the département, consultants, experts and representatives of international organizations). The long duration of my fieldwork made it possible to grasp the process of the creation and "adaptation" of school statistics from the beginning of the school year until the end.

\section{The "adapted" calculation of the number of pupils}

Statistics relating to the number of pupils have always been major representation and control techniques for the administrative management of educational institutions, both at national and local levels. First, they guide the creation of teaching posts, inform the school budget, and shape the allocation of equipment or the construction of classrooms. Second, statistics on pupil numbers inform the State and its international "partners" about the development of the school population. Finally, they provide information on the "moral situation" of the school institution (Briand, Chapoulie and Peretz, 1979: 672). Under the influence of NGOs and donors, who increasingly act as "norm entrepreneurs" (Fichtner, 2012), this moral situation does not only present itself through the "healthy" image of the school with a growing number of boys and girls attending class. It is also defined by its transparent, democratic and 
participatory government, its "good governance", which should include parents. These parents are "responsibilized" by actors of development projects (Merry, 2011: S90) to get involved in the management of the school (including its quantified management), with the aim of achieving development goals, such as girls' education or women's participation in school matters. This approach may create conflicts between parents and school staff, especially if management is linked to financial issues thus creating "technical work in a situation of extraversion" (Samuel, 2013: 271). In addition, the indicators of school development present a stake in (self) control of one's teaching career or a tool of "self-management" (Bruno and Didier, 2013), described here for the case of the school principal of Alafia ${ }^{8}$.

The village called Alafia is located in the north-east of Benin, about $25 \mathrm{~km}$ from the administrative centre of the municipality. In 2013 it counted about 1,175 inhabitants in Alafia Bariba in the centre and 4,757 inhabitants in the surrounding Fulani camps ${ }^{9}$. Its school was officially founded in 1989 with 43 pupils, including 13 girls. The nearest neighbouring primary school is seven kilometres away; a nursery and secondary school $22 \mathrm{~km}$. The village, which does not have electricity or running water, is considered "remote" and "disadvantaged" by the school administration ${ }^{10}$.

The schooling cycle in Alafia has been carried out for a long time on a biennial basis with a new cohort of pupils every two years. This is due to the lack of teachers, pupils and classrooms in rural areas. Normally in Benin, six primary classes (one for each grade) are operated at the same time: the introductory course $(\mathrm{Cl})$, the preparatory course $(\mathrm{CP})$, the elementary level 1 and 2 (CE1/CE2) and the medium level 1 and 2 (CM1/CM2). However, in Alafia one $\mathrm{Cl}$, one CE1 and one CM1 class were opened one year; then, the following year, a CP, a CE2 and a CM2 were opened. The effect of this policy was that repeating pupils were often

\footnotetext{
${ }^{8}$ See also Fichtner (2014b), Fichtner and Jarroux (2015).

${ }^{9}$ The sedentary Bariba or Baatombu and the semi-nomadic Fulani represent the two largest social groups in this field of research (Boesen, Hardung and Kuba, 1998).

10 For a general portrait of this school and its functioning on a daily basis, see the documentary film by Fichtner and Yaméogo (2014).
} 
placed in a grade lower than the grade they were to repeat, and consequently fell behind by two school years instead of just one. Some therefore left school because of demotivation ${ }^{11}$. The biennial recruitment is still effective in many rural schools despite the announcement by the Beninese government that it would ensure the continuity of education over the six years of primary school in line with the objectives of its TenYear Education Sector Development Plan (PDDSE) 2006-2015 ${ }^{12}$. Abandoning the biennial recruitment system is presented as linked to the goal of gradually increasing the national gross enrolment rate for the CM2 from 54\% in 2005 to $110 \%$ in 2015 (République du Bénin, 2006: 94) ${ }^{13}$.

In Alafia, since the construction of a second school building in 2000, it became possible to operate five classes simultaneously, plus one additional class held in a straw shed, if there were enough children to attend and if teaching staff were available, which was not the case every year. The Minister of Primary Education had in fact announced a deficit of 10,000 trained teachers in Benin in 2012/13 (Anonrin, 2013) to teach children in accordance with the international guidelines used in his decennial plan (40 pupils per class, one teacher per class (République du Bénin, 2006: 71) $)^{14}$.

Given the problems associated with the biennial system, it is in the interest of the parents and the principal to open as many classes as possible and to present a growing number of pupils in order to be eligible

\footnotetext{
${ }^{11}$ For example, out of 73 students who started the $\mathrm{Cl}$ in 2007/08 in Alafia, only 15 entered the CM2 in 2012/13.

12 The 2006-2015 Ten-Year Education Sector Development Plan (PDDSE) was drafted by the Government of Benin in order to benefit from a US\$ 76.1 million support from the Fast Track initiative from 2008 onwards.

${ }^{13}$ The gross admission rate is the ratio between the number of pupils admitted to a class regardless of their age and the population of the official age of admission to the cycle. The diagnostic study RESEN initiated by the Ministry in charge of primary education in 2014 and carried out by the Pôle de Dakar, states that $20 \%$ of pupils in Benin attend a school that does not offer the six classes foreseen. In $14.5 \%$ of schools in the country (27.3\% in Borgou/Alibori where the village of Alafia is located), the continuity of school education is not guaranteed according to the study (République du Bénin and Pôle de Dakar, 2014: 90).

${ }^{14}$ The shortage of teachers, or rather the State's hiring of enough trained teachers and their equitable distribution between areas perceived as disadvantaged or developed, has always been a problem in Benin (Tama, 2014).
} 
for the authorization to have additional classes, receive state subsidies, recruit more teachers and obtain means to build supplementary classrooms. Parents wished to enrol their children as early as possible and avoid the risk of repetition over several years caused by biennial recruitment. The principal wished to be recognized by the village population and the school administration as the principal who developed and "completed" the school with a sixth grade before pursuing his career elsewhere.

The extension of the school in Alafia was thus part of the "career plan" of this young principal, son of a Baatonu farmer from the administrative centre of the municipality, who rapidly passed one career step after the next since obtaining his BEPC secondary school diploma and entering the teaching profession in 2003. After attending the teacher training college and obtaining the certificate of professional aptitude for education, he gained his first post as a school principal in Alafia in 2011/12. With the desire to become school inspector and in order to "leave the right traces", he cultivated his reputation, his political and administrative networks, and his relations with the parents, even though they were sometimes "difficult to manage", as he said.

The parents' association was a "privileged partner in school comanagement" (République du Bénin, 2012). However, relations between the principal and the parents were sometimes conflicting, in particular because of the parents associations' relations with development actors who supervised them and disseminated their norms and "modes of associative governance" at the local level (Olivier de Sardan, 2009: 17) ${ }^{15}$.

In Alafia, the parents' committee had been supported since 2011 by the NGO World Education as part of its Community in Action for Girls' Education (CAEF) program, funded by the United States Agency for International Development (USAID). The project asked the parents' association to integrate a woman into their executive office, to found an association of pupils' mothers - perceived as an engine for girls' schooling -, to draw up a list of names of children to be enrolled in school

${ }^{15}$ For other studies on parents' associations in West Africa, see for example Comhaire (2010), Petit and Comhaire (2010). 
on the basis of a household survey in the village, and to organize itself for the follow-up. If the number of children of school age was large enough, the project supported the request for the opening of an introductory course $(\mathrm{Cl})$ omitting the biennial recruitment order, and promised to provide the necessary tables and benches. However, as the principal felt excluded from this procedure, he demanded to check the list drawn up by the parents before it was sent to the school district administration.

To increase the number of pupils from the previous year (208 pupils in five classes), it was necessary to be able to open at least five classes in 2012/13, partly under thatched roofs, until a new school building was built. "And for that, the chances of success are not bad now", explained the principal. A Chinese company, which at that time tarred the main road in the centre of the municipality, had promised to help by building a few school buildings, supporting the Benin government's goal of creating 33,026 new classrooms between 2006 and 2015 to facilitate access to education for all and raise the gross enrolment rate ${ }^{16}$ from $94 \%$ in 2005 to 125\% in 2015 (République du Bénin, 2006: 96, 163). With the parents' association and the teaching staff (a permanent state agent, a contract teacher and a "community" teacher recruited and paid by the parents), the principal decided to go "until the end", that is to say, engage in the opening of six classes, despite difficulties in mobilizing parents to build a straw shed and finding additional teachers ${ }^{17}$. At the end of October 2012, the principal presented the first of three statistical reports to be completed at the beginning, middle and end of the school year. These reports then needed to pass through the offices of the superior administration, namely the school district, the directorate of primary education at departmental

\footnotetext{
${ }^{16}$ The gross enrolment rate corresponds to the "number of students enrolled in a given level of education, regardless of their age, expressed as a percentage of the population of the theoretical age group corresponding to this level of education" (UNESCO Institute for Statistics: http://www.uis.unesco.org, accessed 26/02/2016). The gross enrolment rate may exceed $100 \%$ without indicating that universal enrolment has been completed; this shows either a high repetition rate or a large number of students who are statistically "too young" and/or "too old" in relation to their level of education (which may in itself be a factor or a result of repetition practices) (Gérard and Pilon, 2005: 203).

${ }^{17}$ On the question of the management and distribution of teachers at the local level in Benin, see also Fichtner and Jarroux (2015).
} 
level, and the Ministry's planning and foresight department. On this first "start of school year report" were the names of 82 potential pupils (42 girls) for the new $\mathrm{Cl}$, based on the calculations that the parents' committee had provided for the CAEF project. The total number of pupils at the school was, according to this report, 257 pupils (122 girls).

At the beginning of January, 61 pupils, including 30 girls, and 34 repeaters began their introductory class in a shed built by the parents. The principal explained to me that the difference between the numbers from October (82) and from January (61) was due to the fact that some of the pupils had to be rejected because of their young age and that in any case the October list would always be treated as an estimate. In January 2013, the school's total number of pupils had been reduced to 202 (including 89 girls), six pupils less than in the previous year. These figures were also included in the principal's second report: the "annual primary school census record", transmitted to the school administration in April 2013.

Despite the overall "decline" in pupil numbers, the $\mathrm{Cl}$ class was formally approved as one of five authorized classes, which meant that the principal received, as for all officially approved classes, the amount of FCFA 150,000 $(\sim € 228)$ for the purchase of educational materials and a monthly "allowance" of FCFA 1,000 ( $€ 1.50)$ per class. This subsidy was not related to the "real" number of pupils indicated by the principal, but based on the desirable standard of 40 pupils per class defined in the PDDSE (République du Bénin, 2006: 71). On the other hand, the calculation of the salary of the community teacher paid by the parents, who had been appointed to teach the new class, depended on the total number of pupils in Alafia and was a source of permanent conflict between the parents, the community teacher and the school principal. Officially, the recruitment of community teachers has been forbidden since the campaign to reintegrate them in the contract teacher system in 2008 and in accordance with the principle of gratuity decreed in 2006 by the government. However, in 2012 at least 2,700 community teachers were still declared and tolerated in Beninese schools (Bogino and Sack, 2012: 17).

In July 2013, the community teacher was only paid for five instead of seven months. His monthly salary amounted to FCFA 30,000 ( € 46). 
When I noticed that the total of FCFA 2,000 collected per pupil $(\sim € 3$, an amount defined in consensus during the general assembly of the school), exceeded by far the amount of the community teacher's annual salary $(2000 \times 202=$ FCFA 404,000 ( $€ 611)$, the salary being FCFA 210,000 $(\sim € 318))$, the principal explained that the school's total number of pupils was lower than 202 and that there were financial issues that he could not address, which were "internal business". According to my class observations there were around 177 pupils at school, but according to the "year-end report" completed by the principal in July 2013, there were 194 pupils in total (including 84 girls). However, even with this "adapted" number, the parents' association, together with the principal, could use part of the budget collected from the parents for other purposes if everyone paid.

The use of statistics for collective financial or material gain was not unknown to the government educational administration. The inspector, a direct superior of the principal, explained:

"The reliability of school statistics that the principals send us is really a problem. Since the food [for the canteens] is being sent in proportion to the number of pupils [...], the principals try to manipulate statistics to have pupils in all classes in order to get enough food. And then they get into an embarrassing situation because it is necessary to maintain these same statistics, that they gave in relation to the canteen, to the school [exam] administration."

The deputy head of school organization and planning at the directorate at departmental level added:

"Staff at the local school district administration are trained to fill in the forms with the principals. Afterwards, it is up to us to go on the ground to check the forms and to check them in the schools. We even go into classes to count pupils and there we realize that the principals inflate the numbers. We call them to the DDEMP (Departmental Directorate of Maternal and Primary Education) to force them to correct their figures. And when they are forced to move for that, they soon learn that it is not good. That's how we manage it. [...] But it is true that our missions are complicated. From time to time you have to travel by motorbike, without the necessary means... Then, you govern by checking a sample of schools." 
So-called "bush schools", such as that in Alafia, are not often included in this sample. In 2012/13 there was no check on its statistics.

The fabrication of statistics therefore becomes an act of "juggling" to present a realistic and harmonious image of the progressive development of the school and its "good governance", as well as to achieve the different objectives (financial, careerist) of the actors involved in its production. Control by numbers of school management, its evolution and its "moral situation", was established to address the mistrust of the government and manage its geographical distance from schools (Porter, 1995: ix; Rottenburg, 2002: 217). However this technique is limited by the instrumental character of the figures in the school arena and is hence an insufficient means for verification of what actually goes on inside the school. The different reports of pupil numbers in Alafia produced by parents and the principal constitute micro-political tools in a precarious situation in relation to the need for teachers and classrooms. The "informal" context of the community teachers' recruitment favours the use of statistics to "capture" funding and other benefits. At the same time, it is the necessity of a "partnership" model of school management, and the requirement to present a growing school record, that produce these "register politics" (Rottenburg, 2002: 182; Samuel, 2013). These practices do not necessarily aim "to establish their objectivity by conformity to an external reality, but by their conformity with the rules of a development project", common in the "world of aid" according to Rottenburg (2002: 180). However, even if these figures are described as "poor numbers" (Jerven, 2013), as weak representatives of reality, they have real effects on the actors concerned. They provide schools with access to additional resources such as the donation of the tables and benches for the new $\mathrm{Cl}$ through the CAEF project ${ }^{18}$. Moreover, as political tools of selfmanagement (Shore and Wright, 2000: 62), they can influence the reputation of the principal, the main person responsible for the local production of "his" school's statistics.

\footnotetext{
${ }^{18}$ Curiously, by supporting the opening of a new class through parental engagement, the NGO aimed to increase the schooling rate in the village and, in particular, that of girls. In fact, girls had represented almost half of the total number of pupils for some years. The NGO's work was thus more a matter of maintaining a standard than of introducing it...
} 
Repetition policies, practices and statistics

Several issues discussed above in the calculation of pupil numbers in school also emerge from the analysis of the policies, practices and quantified descriptions of repetition rates at national and local level in Benin. In addition, the case of repetition shows the changing impact of international expertise on educational policies and their representations. What used to be a "normal" pedagogical tool has become a problem under the auspices of international experts, which must be "hidden" in the statistical registers, even though this "problem" continues to be perceived locally as a selection technique which helps to maintain the standard of success for schools and its staff in a competitive environment. The logics and practices of repetition management "for real" and on paper navigate between official standards influenced by discourses on the economic productivity of the developmental framework of Education For All, and "practical norms" (Olivier de Sardan, 2014: 407) oriented towards the institutional efficiency of the school as envisaged by local actors.

At the first staff meeting in October 2012, the principal had not only an idea of the actual and desirable numbers of teachers and pupils in the school, but also of their actual and desirable distribution across different classes. He analyzed the results of the final exam from the previous year, created lists, compared them, counted pupils, sent them from one class to another, and corrected the lists. This process took several weeks. There were repeaters in all classes. In the $\mathrm{Cl}$, there were 34 repeaters among the 61 pupils enrolled, despite the prohibition of repetition in the $\mathrm{Cl}$ grade defined by a decree in 2004 (République du Bénin, 2004). This decree was inspired by the recommendations of international experts arguing that the introductory course should simply make it possible for children to become accustomed to French-language instruction and that the content would be repeated and thoroughly examined in the following grade CP. Furthermore, the repetition between the sub-cycles of CE1/CE2 and $\mathrm{CM} 1 / \mathrm{CM} 2$, introduced as a new structure in 2004, is not officially prohibited, but is also not recommended by the Beninese government, on the advice of donors who have "problematized" repetition practices from the 1980s onwards (DANIDA, AFD and République du Bénin, 2012: 82; République du Bénin and Pôle de Dakar, 2014: 31; World Bank, 2002: 55). 
This "problematization" is part of a discourse on the effectiveness and profitability of the school in the context of Education For All policies (Bernard, Simon and Vianou, 2005; Normand, 2006).

National repetition rates in Benin, that ranged from $24 \%$ to $30 \%$ between 1992 and 2004 (INSAE, 2012; République du Bénin, 2003: 137), were considered by international partners to be too high compared to other (especially Anglophone) countries in the region, and too costly in economic and psychological terms ${ }^{19}$. Following the ban on repetition at the $\mathrm{Cl}$ level in January 2004, and the implementation of the policy that pupils automatically pass within sub-cycles (i.e. from $\mathrm{Cl}$ to $\mathrm{CP}$, from CE1 to CE2, and from $\mathrm{CM} 1$ to $\mathrm{CM} 2$ ), the national repetition rate fell to $17 \%$ in 2005 and to $8 \%$ according to the government ( $10 \%$ according to the Pôle de Dakar) in 2006 before rising to $13 \%$ according to the government (16\% according to the Pôle de Dakar) in 2011 (INSAE, 2012; République du Bénin and Pôle de Dakar, 2014: 126) ${ }^{20}$. The international benchmark to be reached in 2015, which is included in Benin's sectoral plan, is fixed for $10 \%$ (République du Bénin, 2006: 79).

If we look at the situation in Alafia's school, neither the prohibition of repetition at the $\mathrm{Cl}$ nor the automatic passage between sub-cycles were applied. In the various statistical sheets which the principal had completed at different times of the school year, the repetition rate varied between $20 \%$ and $28 \%$ for the total number of pupils. Regarding the distribution of repeaters in the various classes, the lists showed different figures for different classes which deviated from the "real" number of repeaters. At the beginning of the school year there were 34 repeaters in $\mathrm{Cl}, 12$ in $\mathrm{CP}$, 0 in CE1, 15 in CE2 and 12 in CM1, thus 73 repeaters in total. On the annual census sheet completed in April 2013, there were no repeaters in $\mathrm{Cl}, 9$ in

\footnotetext{
${ }^{19}$ Various studies explain the high rate of repetition in Francophone and Portuguese-speaking countries in comparison with Anglophone countries in Africa by the colonial legacy of a wider shared acceptance of repetition as a pedagogical tool in France, Belgium and Portugal (Bernard, Simon and Vianou, 2005: 20; Charton, 2012: 14; CONFEMEN, 2011: 72).

${ }^{20}$ It is very common to see a difference between the statistics published by the State and those published by international organizations, without any explanation of these differences for instance in relation to their databases.
} 
CP, 0 in CE1, 11 in CE2 and 20 in CM1, thus 40 in total and with a different distribution across grades.

The principal explained to me the "real" repetition practices in the $\mathrm{Cl}$, which were not on the census list, arguing that the children are "very immature", often educated too early at the age of four instead of six years ${ }^{21}$ because of the absence of a nursery school in the village. Until the opening of the $\mathrm{Cl}$, the 34 repeaters had been tolerated as "free auditors" in the CP. However, they were not integrated into the course. The same thing happened to the 15 repeaters of the CE2, who found themselves without an authorized class. Initially they were placed in the CE1 as passive auditors, foreseen to spend a school year before repeating the CE2. However, throughout the school year, the principal encouraged the CE1 teacher to practice multi-grade teaching (whereby pupils in grades CE1 and CE2 were taught in the same class under the same teacher). In fact, he created a sixth unofficial class, so that by the end of the school year, 10 of the 15 pupils of CE 2 passed into CM1 and only five were repeating another year.

According to the principal and the teachers of Alafia, the level of pupils was too low for an "automatic passage", as was recommended between grades. In other words, if the pupils did not repeat, the higher grade teachers who would receive them would have additional difficulties because they would not have the capacity to respond specifically to the needs of "weak" pupils. Those children who did not exceed $50 \%$ of the 20 points to be reached in the monthly and quarterly evaluations had to repeat, even between sub-cycles. The principal looked particularly at the 17 candidates who entered his final class, the $\mathrm{CM} 2$. Pupils who had already repeated several times were, if necessary, expelled from school: "They will infect others with their weak points. Here, one should note: end of schooling!" he said. Successful completion of the final exam by his pupils was very important in measuring and assessing his "success" as a teacher and principal in competition with other schools. If less than $20 \%$ of his

\footnotetext{
${ }^{21}$ The age of the children is often estimated, most of them not having a birth certificate until the end of primary school, when it becomes a necessary document in order to register for the final exam.
} 
pupils passed the final exam, he was likely to be questioned by his superiors.

The practice of repetition is in this context not a pedagogical resource to help pupils develop at their own pace, but rather a means of selection to create a homogeneous level among the pupils in the classroom, which allowed for a certain success rate in exams, and helped to retain the reputation of the school and its staff. In fact, the key concept which informed the principal's actions was "school effectiveness". This is not measured in terms of economic costs per pupil, the key measure for international agencies such as UNESCO and the World Bank, which calculate the efficiency and effectiveness of education systems on a global scale, but in terms of success in exams (which does not necessarily reflect the skills acquired by the pupils (Normand, 2006)). The principal was aware, however, that his selective practice was contrary to the slogan "No Child Left Behind" of the official policy inspired by the educational practice in the United States. It was based on the perception that a system that values only performance needs support and catch-up measures (Vinokur, 2008: 6). "Yayi Boni said: there is no exclusion", the principal said, quoting the Beninese president. "Every child should have the right to receive education according to his needs." However, this was according to him incompatible with the demands and realities of the terrain. The production of statistics is, in this sense, once again, more of a micro-political "listing" technology (Rottenburg, 2002: 182) of the school and the selfmanagement of its actors, than an indicator and a credible instrument of international and national education policies. The figures "on paper" gave little information on concrete practices, but both contributed to the production of school realities.

\section{Conclusion}

Analyzing the "adapted" fabrication of pupil numbers and repetition rates at the micro level of the school in Alafia opens a perspective for understanding how actors make, represent and govern their school by numbers in the context of the global initiative of Education For All. The fact that both of these numbers are data that feed into composite indicators 
and (micro)political instruments makes their readability and "objective" or bureaucratic use outside of their production context difficult.

The framework for the accelerated implementation of the Education For All (EFA-Fast Track) objective, designed around the keywords of educational partnership, voluntarism and efficiency, implies a change in development politics with regard to the function of school statistics. According to this logic, the giving of aid is legitimized on political will geared towards achieving educational progress (increasing numbers of pupils enrolled, decreasing repetition rates), as expressed in national plans and through the implementation of benchmarks and measures to achieve them. It is not the red figures ("deficits") that push international partners to intervene and provide support, but the black figures ("assets"); the "good" numbers. The implicit requirement of "good" numbers by these policies does not necessarily lead to one "realistic" image of the school situation, which would then constitute an "objective" basis for the steering of educational systems and data-based decision making. Instead, it leads to small arrangements by actors at different levels, favouring the disguise of reality and producing several paper realities, legitimizing the different objectives of the actors involved in the school arena.

In the example of the negotiation of pupil numbers in Alafia, the nongovernmental partners of the CAEF project delegated to parents the responsibility of the creation of a new introductory class $(\mathrm{Cl})$ and the management of the community teacher, according to their own standards of "associative" governance. As for the school principal, in order to run his school, manage the budgetary stakes and develop his career positively through a "healthy" school, he demanded to regain control of the fabrication of the $\mathrm{Cl}$ class, both on lists and in practice. Thus, school statistics are not only used to report and inform about school situations, they also present resources and conditions of control - and thus bureaucratic power - for various actors. Remote government control over isolated areas, and international projects' control of school development, is limited - or in fact challenged - by school principals' locally-exercised control of the representation of their institutions.

These aspects are also visible through the example of the policies and practices of repetition. Here we see the changing prescriptive influences of 
international expertise on national education policy and its management at the local level. These influences are manifested on paper in education sectoral development plans and school statistics, but they do not necessarily affect the practices of the actors on the ground, and if they do, not in the way desired by the initiators of these policies. The practice of the biennial recruitment is, for example, one of the factors compromising the fabrication of a school according to official standards; a factor that does not appear at first sight in the statistics. However, the "real" school cannot be understood simply as a deviance from the "ideal/imagined" school. The two are intimately linked in the (self) governing discourses and practices of their actors, as in their quantified images.

Understanding the logics underlying the local fabric of school statistics is indicative of the limitations of the management of education systems by the technologies of quantification and the evaluation of EFA goals by the indicators derived from them. Understanding the complexity of the chain of production, transformation and (re)composition of these indicators, and their political entanglements between the local and the global, is a goal that deserves to be pursued through further field research. This article was only able to illuminate this process at the level of the school arena, the first link in this chain, which, nonetheless, is understudied in the analysis of school statistics. However, following the trajectories of numbers from their "origins" in the office of a school principal, through the various decentralised and central government educational administrations, to the data tables produced in the UNESCO or the World Bank's statistical institutes, promises to be rich in insights on the contextualized political manipulation of the technologies of neo-liberal bureaucracy today.

\section{Bibliography}

ABRAHAMSEN R., 2004, "The Power of Partnerships in Global Governance", Third World Quarterly, 25(8) : 1453-1467.

ANONRIN K.O., 2013, "Audition des Ministres à propos du projet de budget de l'État, 2014 : Trois Ministres dont Aké Natondé bouclent la liste hier au Parlement", Fraternité, http://www.fraternitebj.info/POLITIQUE/article/ audition-des-ministres-a-propos-du (accessed 17/12/2013). 
BALL S., 1987, The Micro-Politics of the School. Towards a Theory of School Organization, London/New York, Methuen.

BERNARD J.-M., SIMON O. and VIANOU K., 2005, Le redoublement: mirage de l'école africaine?, Dakar, CONFEMEN.

BIANCHINI P., 2008, "Education as a market: views from Africa", L'école démocratique, http://www.skolo.org/spip.php?article951\&lang=fr (accessed 26/01/2014).

BIERSCHENK T. and OLIVIER DE SARDAN J.-P. (eds.), 1998, Les pouvoirs au village. Le Bénin rural entre démocratisation et décentralisation, Paris, Karthala.

BOESEN E., HARDUNG C. and KUBA R. (eds.), 1998, Regards sur le Borgou. Pouvoir et altérité dans une région ouest-africaine, Paris, L'Harmattan.

BOGINO P. and SACK R., 2012, "Rapport d'évaluation du Plan décennal de développement du secteur de l'éducation (PDDSE) actualisé, phase 3 : 2013-2015 pour l'endossement par le Groupe Local Éducation et soumission au Partenariat Mondial pour l'Éducation", http://www. globalpartnership.org/fr/download/file/fid/2170 (accessed 02/10/2014).

BRIAND J.-P., CHAPOULIE J.-M. and PERETZ H., 1979, "Les statistiques scolaires comme représentation et comme activité", Revue française de sociologie, 20(4) : 669-702.

BRUNO I. and DIDIER E., 2013, Benchmarking. L'État sous pression statistique, Paris, Zones.

CHARTON H., 2012, "La mesure de la qualité en éducation en Afrique ou les instruments d'une fausse dépolitisation", presentation at the conference : La mesure du développement, GEMDEV-UNESCO, Paris.

COMHAIRE G., 2010, "Les associations de parents en Afrique subsaharienne francophone", in PETIT P. (ed.), Société civile et éducation, Louvain-laNeuve, Academia-Bruylant : 49-73.

CONFEMEN, 2011, “Qualité de l'éducation: un enjeu pour tous. Constats et perspectives", document de réflexion et d'orientation, http://www. confemen.org/wp-content/uploads/2012/01/DRO-SUR-LA-QUALITE-DE-LEDUCATION.pdf (accessed 14/01/2014).

CUSSO R., 2008, "Strengths and Limits of Data: From Goal- to Conditionalityindicators in Education", in RESNIK J. (ed.), The Production of Educational Knowledge in the Global Era, Rotterdam/Taipei, Sense Publishers : 93106. 
DANIDA, AFD and RÉPUBLIQUE DU BÉNIN, 2012, "Évaluation à mi-parcours du Plan décennal de développement du secteur de l'éducation du Bénin (PDDSE 2006-2015)", https://www.afd.fr/fr/evaluation-mi-parcours-duplan-decennal-de-developpement-du-secteur-de-leducation-du-beninpddse-2006-2015 (accessed 26/03/2019).

DELEIGNE M.-C., 2004, “La mesure statistique et ses limites : l'exemple du système scolaire malgache", Cahiers de la recherche sur l'éducation et les savoirs, $3: 171-193$.

DESROSIÈRES A., 2000, La politique des grands nombres. Histoire de la raison statistique, Paris, La Découverte.

FICHTNER S., 2012, The NGOisation of Education. Case Studies from Benin, Köln, Köppe.

FICHTNER S., 2014a, "Global Governance by Numbers? A Local Perspective", Norrag News, 51 : 49-50.

FICHTNER S., 2014b, "Head Teachers as Central Actors in Glocal Education Politics. A Real Story from Benin", Norrag News, 50 : 118-120.

FICHTNER S. and JARROUX P., 2015, "La micropolitique de l'école primaire au Bénin. Une ethnographie combinée des directeurs et inspecteurs", Politique Africaine, special issue, 139 : 63-81.

FICHTNER S. and YAMÉOGO P., 2014, "Ici, on se débrouille. Le quotidien des écoles au Bénin", film documentaire, http://web-edu.tv/spip.php?article114 (accessed 30/03/2015).

FOUCAULT M., 1991, "Governmentality", in BURCHELL G., GORDON C., MILLER P. (eds.), The Foucault effect: studies in governmentality, Chicago, Chicago University Press : 87-104.

FOUCAULT M., 1994 (1988), "La technologie politique des individus", Dits et écrits, tome IV, Paris, Gallimard : 813-828.

GARCIA S., 2002, "La "fabrique" de la démocratisation scolaire: indicateurs statistiques et "consignes" d'évaluation", Cahiers de la recherche sur l'éducation et les savoirs, $1: 265-285$.

GERARD E. and PILON M., 2005, "Le niveau de scolarisation au primaire: entre mesures, usages et enjeux", Cahiers de la recherche sur l'éducation et les savoirs, hors-série, $1: 201-222$. 
HIBOU B., 2013, "Introduction : La bureaucratisation néoliberale, ou la domination et le redéploiement de l'État dans le monde contemporain", in HIBOU B. (ed.), La bureaucratisation néolibérale, Paris, Éditions La Découverte : 720.

INSAE (Institut national de la statistique et de l'analyse économique), 2012, Indicateurs scolaires au niveau de l'enseignement primaire au Bénin de 2003 à 2012, manuscript, Cotonou.

JERVEN M., 2013, Poor Numbers: How We Are Misled by African Development Statistics and What to Do about It, Ithaca/London, Cornell University Press.

LANGE M.-F., 2003, "École et mondialisation. Vers un nouvel ordre scolaire ?", Cahier d'Études Africaines, 169-170 : 143-166.

LAVAL C. and WEBER L. (eds.), 2002, Le nouvel ordre éducatif mondial. OMC, Banque mondiale, OCDE, Commission européenne, Paris, Éditions Nouveaux regards et Syllepse.

MERRY S.E., 2011, "Measuring the World: Indicators, Human Rights, and Global Governance: with CA comment by John M. Conley", Current Anthropology, 52(S3) : S83-S95.

NORMAND R., 2005, "La mesure de l'école: politique des standards et management par la qualité", Cahiers de la recherche sur l'éducation et les savoirs, hors-série, $1: 67-82$.

NORMAND R., 2006, "L'école efficace ou l'horizon du monde comme laboratoire", Revue française de pédagogie, 154 : 33-44.

OLIVIER DE SARDAN J.-P., 2009, "Les huit modes de gouvernance locale en Afrique de I'Ouest", Études et Travaux du LASDEL, 79, http://www.lasdel.net/ images/etudes_et_travaux/Les_huit_modes_de_gouvernance_locale_en _Afrique_de_I_Ouest.pdf (accessed 26/03/2019).

OLIVIER DE SARDAN J.-P., 2014, "The Delivery State in Africa. Interface Bureaucrats, Professional Cultures and the Bureaucratic Mode of Governance", in BIERSCHENK T. and OLIVIER DE SARDAN J.-P. (eds.), States at Work. Dynamics of African Bureaucracies, Leiden/Boston, Brill : 399-429.

OZGA J. et al., 2009, "ECRP05: Governing by Numbers: Data and Education Governance in Scotland and England: Full Research Report. ESRC End of Award Report", Swindon, ESRC. 
PETIT P. and COMHAIRE G., 2010, "Introduction : Les associations de la société civile et le partenariat éducatif", in PETIT P. (ed.), Société civile et éducation, Louvain-la-Neuve, Academia-Bruylant : 15-47.

PORTER T., 1995, Trust in Numbers. The Pursuit of Objectivity in Science and Public Life, Princeton, Princeton University Press.

RÉPUBLIQUE DU BÉNIN, 2003, Plan d'actions national du Bénin pour la mise en oeuvre du programme Éducation pour tous, Porto Novo, ministères en charge de l'éducation.

RÉPUBLIQUE DU BÉNIN, 2004, Arrêté N001/MEPS/CAB/DC/SGM/DEP/SP portant réglementation du redoublement au Cours d'Initiation à l'enseignement primaire en République du Bénin, Porto Novo, ministère de l’Éducation primaire et secondaire.

RÉPUBLIQUE DU BÉNIN, 2006, Plan Décennal de Développement du Secteur de l'Éducation 2006-2015, Porto Novo, ministères en charge de l'éducation.

RÉPUBLIQUE DU BÉNIN, 2012, Guide d'Appui à la Gestion de l'École dans le Contexte de la Décentralisation, Porto Novo, ministère des Enseignements maternel et primaire.

RÉPUBLIQUE DU BÉNIN and PÔLE DE DAKAR, 2014, Rapport d'état du système éducatif (RESEN). Pour une revitalisation de la politique éducative dans le cadre du programme décennal de développement du secteur de l'éducation, Dakar, IIEP-UNESCO.

ROSE N., 1991, "Governing by Numbers: Figuring out Democracy", Accounting, Organizations and Society, 16(7) : 673-692.

ROTTENBURG R., 2002, Weit hergeholte Fakten: Eine Parabel der Entwicklungshilfe, Stuttgart, Lucius und Lucius.

ROTTENBURG R, MERRY S.E., PARK S.-J. and MUGLER J. (eds.), 2015, The World of Indicators. The Making of Governmental Knowledge through Quantification, Cambridge, Cambridge University Press.

SAMUEL B., 2013, "L'"Éducation pour tous" au Burkina Faso. Une production bureaucratique du réel", in HIBOU B. (ed.), La bureaucratisation néolibérale, Paris, Éditions La Découverte : 262-290.

SHORE C. and WRIGHT S., 2000, "Coercive Accountability. The Rise of Audit Culture in Higher Education", in STRATHERN M. (ed.), Audit Cultures: Anthropological Studies in Accountability, Ethics and the Academy, London, Routledge : 57-89. 
TAMA C., 2014, Être enseignant au Bénin. Les mutations d'un groupe professionnel, Köln, Köppe.

VINOKUR A., 2008, "Les nouveaux enjeux de la mesure de la qualité en éducation", Revue inDIRECT, 12 : 1-14.

WORLD BANK, 2002, "Le système éducatif béninois. Performances et espaces d'amélioration pour la politique éducative", Departmental Working Paper.

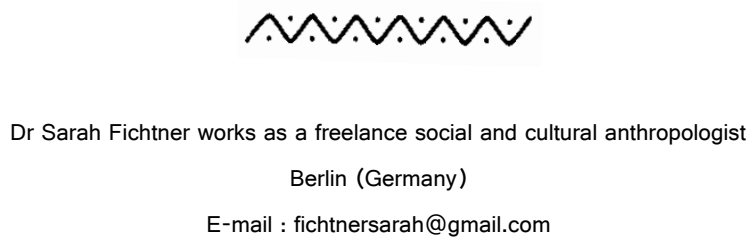

